\title{
Thermophotovoltaic Cell Temperature Measurement Issues
}

T. Moriarty and K. Emery

National Renewable Energy Laboratory

Presented at the 4th Conference on Thermophotovoltaic Generation of Electricity Denver, Colorado October 11-14, 1998

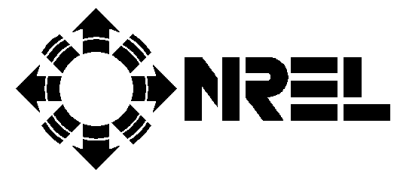

National Renewable Energy Laboratory 1617 Cole Boulevard Golden, Colorado 80401-3393

A national laboratory of the U.S. Department of Energy Managed by Midwest Research Institute for the U.S. Department of Energy under contract No. DE-AC36-83CH10093

Work performed under task number WU6H0205

November 1998 


\begin{abstract}
NOTICE
This report was prepared as an account of work sponsored by an agency of the United States government. Neither the United States government nor any agency thereof, nor any of their employees, makes any warranty, express or implied, or assumes any legal liability or responsibility for the accuracy, completeness, or usefulness of any information, apparatus, product, or process disclosed, or represents that its use would not infringe privately owned rights. Reference herein to any specific commercial product, process, or service by trade name, trademark, manufacturer, or otherwise does not necessarily constitute or imply its endorsement, recommendation, or favoring by the United States government or any agency thereof. The views and opinions of authors expressed herein do not necessarily state or reflect those of the United States government or any agency thereof.
\end{abstract}

Available to DOE and DOE contractors from:

Office of Scientific and Technical Information (OSTI)

P.O. Box 62

Oak Ridge, TN 37831

Prices available by calling 423-576-8401

Available to the public from:

National Technical Information Service (NTIS)

U.S. Department of Commerce

5285 Port Royal Road

Springfield, VA 22161

703-605-6000 or 800-553-6847

or

DOE Information Bridge

http://www.doe.gov/bridge/home.html 


\title{
Thermophotovoltaic Cell Temperature Measurement Issues
}

\author{
T. Moriarty and K. Emery
}

NREL, 1617 Cole Blvd., Golden, CO, 80401

\begin{abstract}
The power produced by photovoltaic devices changes with temperature, ranging from $0.1 \%$ to nearly $1 \%$ per degrees Celsius depending on the structure. The temperature across the surface of TPV cells will vary depending on the amount of absorbed power. Thus the temperature over a region of a wafer where there is no cell will be different from a region of the wafer containing a cell with an antireflection coating and back surface reflector. Vacuum hold-downs or back surface probes may result in local hot spots. Bonding a cell to a heat sink may not be practical in a research environment, and a temperature gradient between the heat sink and space-charge region will still exist. Procedures for determining the current versus voltage $(I-V)$ characteristics at a given temperature are discussed. For continuous illumination measurement systems, the temperature of the heat sink or backside of the device can be directly measured. The temperature can also be inferred by placing the sample at a known temperature in the dark, and monitoring the opencircuit voltage $\left(V_{o c}\right)$ as a high-speed shutter is opened. The maximum $V_{o c}$ from this method corresponds to the temperature in the dark and the plate temperature can then be lowered until this maximum $V_{o c}$ is reached. The temperature can also be indirectly determined from the dark $I-V$ characteristics, assuming negligible series resistance in the ideal case that the voltage in the dark at a given current and temperature corresponds to the $V_{o c}$ and short circuit voltage $\left(I_{s c}\right)$ at that temperature. A high-intensity flash simulator will produce negligible cell heating during the flash and therefore the cell temperature may be easily set before the flash.
\end{abstract}

\section{INTRODUCTION}

Many thermophotovoltaic (TPV) device performance parameters, and hence overall power output, vary with device space-charge region temperature. As with any photovoltaic device, it is important to quantify these variations in the form of temperature coefficients for the essential current versus voltage $(I-V)$ parameters. It is even more important for TPV devices because they are likely to be tested and operated in harsh conditions at elevated temperatures and with large temperature gradients. This paper discusses some difficulties in measuring TPV device temperatures under testing conditions, consequences of inaccurate temperature measurements, methods for mitigating the difficulties, and temperature coefficients for the open-circuit voltage $\left(V_{o c}\right)$, maximum power $\left(P_{\max }\right)$, fill factor $(F F)$, and the short-circuit current $\left(I_{s c}\right)$ for a InGaAs TPV device fabricated at NREL with an energy gap of $0.6 \mathrm{eV}$. 


\section{CAUSES OF TEMPERATURE GRADIENTS}

Vacuum holes, back surface voltage or temperature probes or voids in bonding solder may all cause localized hot spots in a cell. Figure 1 shows the temperature increase of a $3 \mathrm{~mm} \times 3 \mathrm{~mm}$ cell when placed in various positions over a back surface voltage probe in a 1-mm-diameter hole. The short-circuit current density $\left(J_{s c}\right)$ was the same in each case, about $1.5 \mathrm{~A} / \mathrm{cm}^{2}$, and the cell temperature in the dark was $25^{\circ} \mathrm{C}$. The temperature was determined using the "fast V" method explained below. Although the probe occupies only about $9 \%$ of the back surface area of the cell, its presence at the center of the cell results in a $34^{\circ} \mathrm{C}$ temperature rise when light is applied. However, when the hole is 2 millimeters beyond the perimeter of the cell, but still under the wafer, the temperature rise is only $14^{\circ} \mathrm{C}$.

Top surface voltage and current probes may cause temperature gradients in a cell if they are exposed to light and subsequently heated. The probes may be shielded from the light, but shielding increases the probe size and may reduce light uniformity. Probes may also conduct heat to or away from the sample and will shade the portion of the cell that they touch.

The quality of the temperature plate surface finish may have a strong effect on the difference between the illuminated and nonilluminated temperatures. Figure 2 shows the cooling-plate temperature adjustment required to return a GaInAs cell to its dark temperature after it has been illuminated on two different cooling plates. One is thermoelectrically cooled nickel-plated aluminum, and after 10 years of use in the laboratory has a visibly poor surface quality (machining marks, scratches, and dents). The other is a new, commercially available, water-cooled plate with a high-quality surface finish and high thermal conductivity. The same source and optics were used in each case
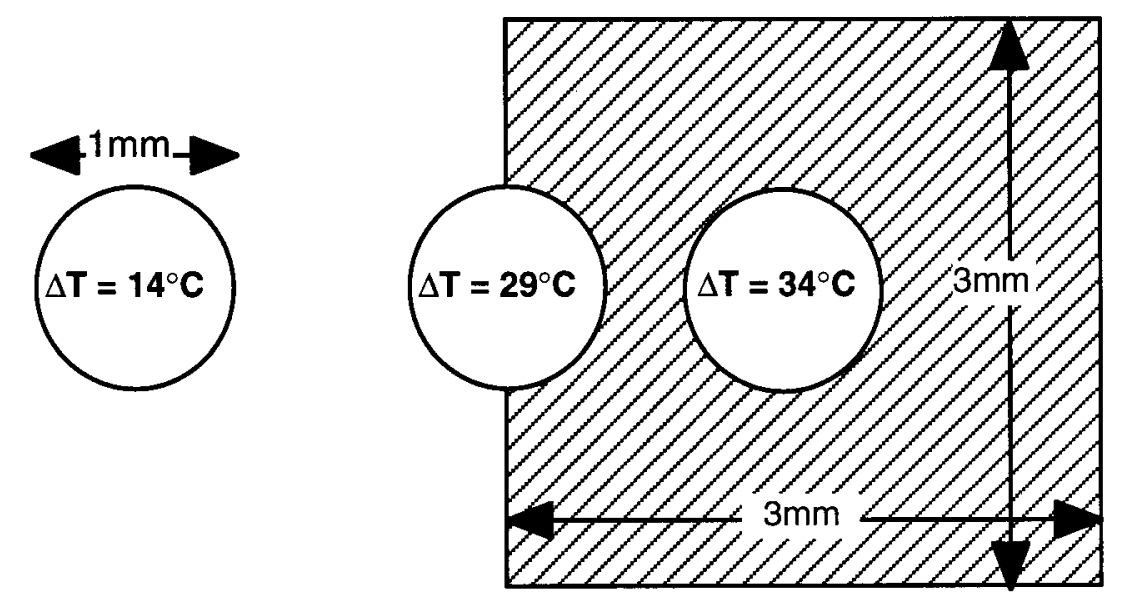

FIGURE 1. The effect of a 1-mm-diameter hole in the cooling plate below a wafer containing a 9-mm $\mathrm{m}^{2}$ GaInAs cell. The cell temperature rise for three different positions is shown. In each case the plate temperature was $25^{\circ} \mathrm{C}$, the light intensity was the same, and short-circuit current density was about $1.5 \mathrm{~A} /$ 
and the fast $\mathrm{V}$ method was used to determine the temperature change.

The nonuniform temperature distribution that results from holes will yield reduce power, and for a given current density $V_{o c}, F F$, and $P_{\max }$ will all suffer [1]. The drop in $V_{o c}$ caused by temperature gradients across a cell becomes greater as illumination increases, and calculations of the ideality factor, $\mathrm{n}$, based on $V_{o c}$ versus $\log J_{s c}$ may yield a diode quality factor of less than one [2].

Temperature gradients caused by nonuniform illumination become more severe as the cell size increases. Of course, measurements of the $I-V$ characteristics of series connected cells with nonuniform light are subject to other errors since voltage contributions will vary among cells and current will be limited by the cell exposed to the least amount of light.

\section{METHODS FOR MEASURING TEMPERATURE}

\section{Direct Contact}

Direct contact measurement is the easiest method conceptually and to implement but may yield very misleading results. A temperature probe on the top surface is exposed to intense IR from one side; it casts a cooling shadow on the spot that it is contacting and may work as a heat sink on the other [3]. It is usually necessary to hold the temperature plate at a level much lower than the desired junction temperature (see Figure 2), so if a bottom contact probe is in thermal contact with the cooling plate it will report a temperature that is lower than the junction temperature. If a bottom contact probe is thermally isolated from the plate, then it is, in effect, a hole under the wafer and may report a temperature much higher than adjacent areas on the wafer (as in Figure 1).

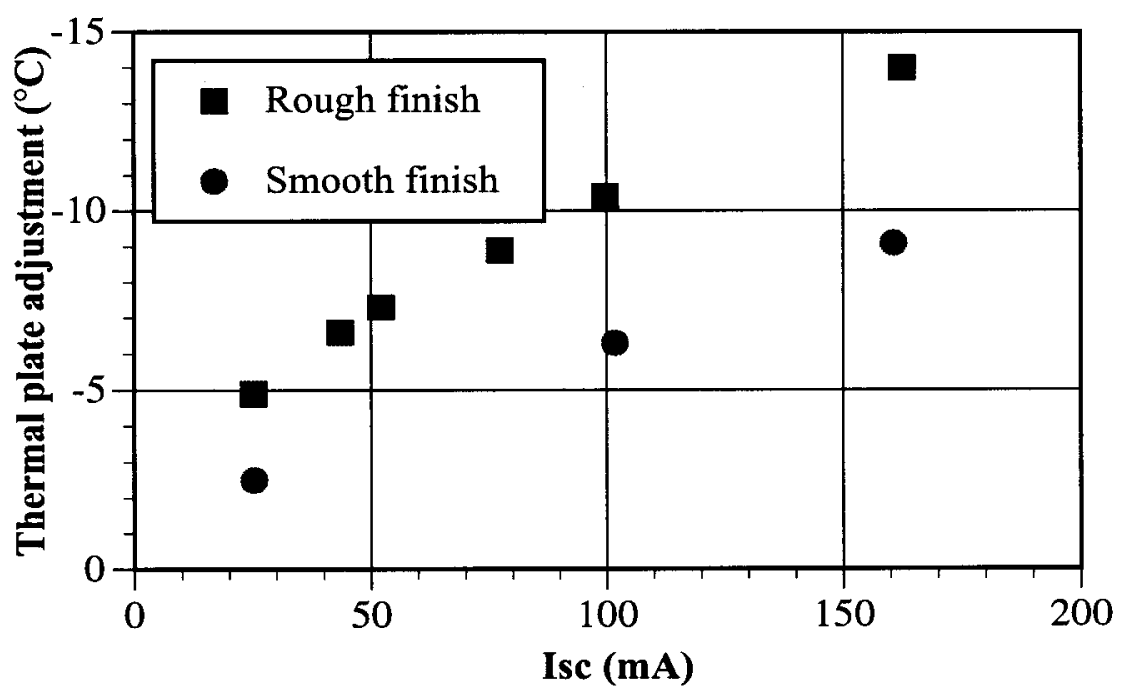

FIGURE 2. The cooling-plate temperature adjustment necessary to return a cell to $25^{\circ} \mathrm{C}$ after continuous illumination depends in part on the light level and surface quality of the plate. 


\section{The Fast V Method}

When a cell in the dark is suddenly exposed to light, there is a rapid increase in cell temperature. After its initial increase, $V_{o c}$ drops asymptotically to a level that reflects its increased steady-state temperature. If the cooling-plate temperature is adjusted until $V_{o c}$ is the same as it was immediately after exposure to the light, then it can be assumed that the cell temperature has returned to nearly its initial value as well. This procedure assumes that $V_{o c}$ can respond in less than $1 \mathrm{~ms}$ to light being turned on, and the temperature rise during the first ms that the shutter is opening is negligible. The effect of $V_{o c}$ response time can be mitigated by letting the sample sit at $V_{o c}$ at a light level that causes negligible heating prior to opening the shutter. The fast $\mathrm{V}$ method for setting cell temperature takes advantage of this effect. This method uses a closed high-speed shutter to block the light from the cell while the cell temperature comes to equilibrium with the cooling plate. Then, the shutter is opened and $V_{o c}$ measured every few milliseconds (see Figures 3 and 4). The change in cell temperature, $\Delta T$, between the voltage measurements immediately

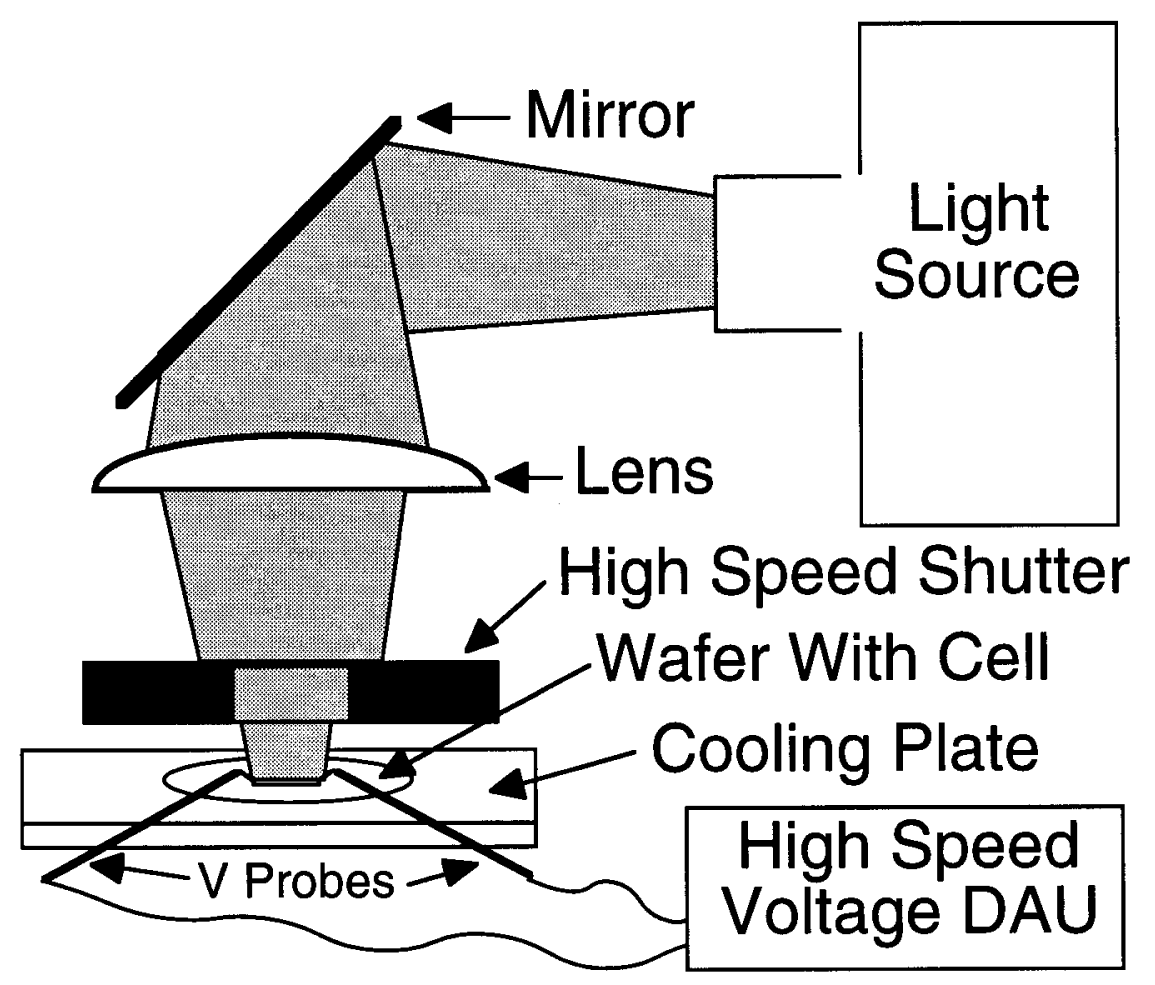

FIGURE 3. Apparatus for fast $V$ measurement of the drop in $V_{o c}$ as device heats. The data acquisition unit (DAU) collects voltage data every millisecond or longer starting before shutter opens. The cooling plate reduces the device temperature until $V_{o c}$ rises to the level that occurred immediately after the shutter opened. 


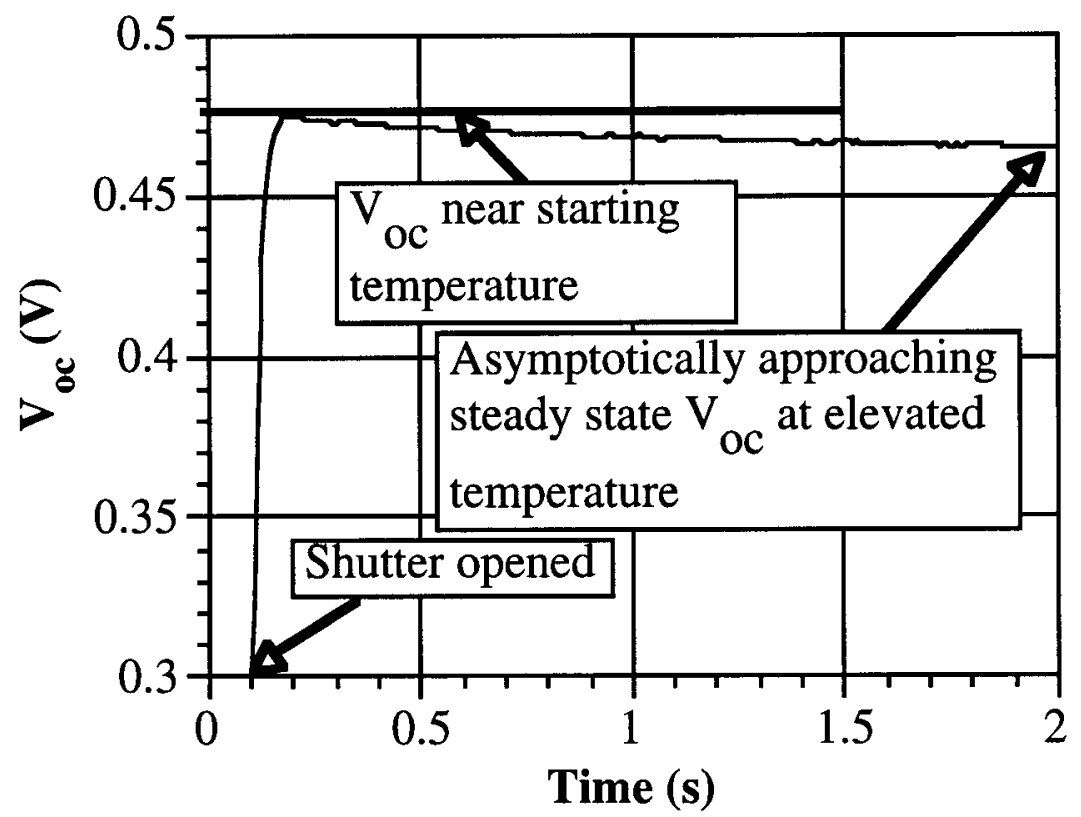

FIGURE 4. $V_{o c}$ rises rapidly after the shutter is opened, but immediately starts to drop as the cell heats in a fast $\mathrm{V}$ temperature measurement. The cell may be brought back to its dark temperature by adjusting the cooling plate temperature until $V_{o c}$ rises back to the value that occurred immediately after the shutter was opened.

before and after the shutter opens represents the inherent error in this method and may be estimated [4] by

$$
\Delta T=\frac{Q t^{1 / 2}}{\sqrt{\pi \rho c k}}
$$

where $Q$ is the heat flux or total irradiance, $t$ is the time that the sample is exposed to light, $\rho$ is the density, $c$ is the specific heat, and $k$ is the thermal conductivity. For an InP substrate $\rho=4.8 \mathrm{~g} / \mathrm{cm}^{3}, c=0.322 \mathrm{~J} \mathrm{~g} \mathrm{~g}^{-1}{ }^{\circ} \mathrm{C}^{-1}$ and $k=0.68 \mathrm{~W} \mathrm{~cm}^{-1}{ }^{\circ} \mathrm{C}^{-1}$ [5]. Assuming a worst-case scenario of all incident light being absorbed, a $0 \%$ efficient cell, and a total

$$
\Delta T=27.5 t^{1 / 2} .
$$

power density $Q$ of $50 \mathrm{~W} / \mathrm{cm}^{2}$, then the expected temperature rise is If the time between voltage measurements is $5 \mathrm{~ms}, \Delta T=2.1^{\circ} \mathrm{C}$.

The fast $\mathrm{V}$ method is limited by the size of the shutter, the $V_{o c}$ response time to a transient light pulse, and the shutter speed. Its advantage is that it allows the spacecharge- region temperature to be set to within the uncertainty discussed above and given in Equation (2). 


\section{Dark I-V}

The $I-V$ characteristic of a diode with low series resistance, large shunt resistance, diode quality factor $(n)$, dark current $\left(I_{0}\right)$, and illumination $\left(I_{L}\right)$ can be written as

$$
I=I_{0}\left\{\exp \left[\frac{q V}{n k T}\right]-1\right\}-I_{L}
$$

Then at $\mathrm{V}_{\text {oc }}$

$$
I_{L}=I_{0}\left\{\exp \left[\frac{q V o c}{n k T}\right]-1\right\}
$$

Equation (4) is of the same form as the characteristic of the diode with negligible series resistance in the dark, or

$$
I=I_{0}\left\{\exp \left[\frac{q V}{n k T}\right]-1\right\}
$$

Under normal conditions, where the short-circuit current is not affected by series resistance, $I_{L}$ and $I_{s c}$ are identical. So, voltage-current pairs extracted from a dark $I-V$ curve should correspond to $V_{o c}-I_{s c}$ pairs for the same device under illumination at the same temperature, assuming that the $I_{0}$ and $n$ are independent of $I_{L}$. When a voltage-current pair from the dark $I-V$ is "dialed in" at the $I-V$ test bed (as $V_{o c}$ and $I_{s c}$ ) by adjusting light intensity and cooling plate temperature, then it can be assumed that the junction temperature is the same as it was during the dark $I-V$ measurement. An advantage of the dark $I-V$ method of setting temperature over the fast $\mathrm{V}$ method is that it can be used on modules whose performance is sensitive to the spatial uniformity of the light source. Figure 5 compares the voltage-current pairs of a dark $I-V$ with the $V_{o c} I_{s c}$ pairs extracted from a set of $I-V$ curves under various illumination levels for a low series-resistance cell. The dark $I-V$ approach becomes susceptible to large errors at high currents for even relatively small series resistances. If series resistance is included in Equation (5) then,

$$
I=I_{0}\left\{\exp \left[\frac{q\left(V-I R_{s}\right)}{n k T}\right]-1\right\}
$$

So,

$$
\frac{d T}{d R_{s}}=\frac{I(q / n k)}{\ln \left(1+J / J_{0}\right)}
$$

Figure 6 shows the dependence of the temperature uncertainty on $I_{L}$ and $I_{0}$. Notice that for a cell with $I_{L}=0.5 \mathrm{~A}$ and $I_{0}=10 \mu \mathrm{A}$ the uncertainty is more than $0.5^{\circ} \mathrm{C} / \mathrm{m} \Omega$ and increases to $1.0^{\circ} \mathrm{C} / \mathrm{m} \Omega$ at a current of $0.9 \mathrm{~A}$. Because it may be difficult to measure a cell's series resistances to within a few milli-ohms, uncertainties can easily reach several degrees. 


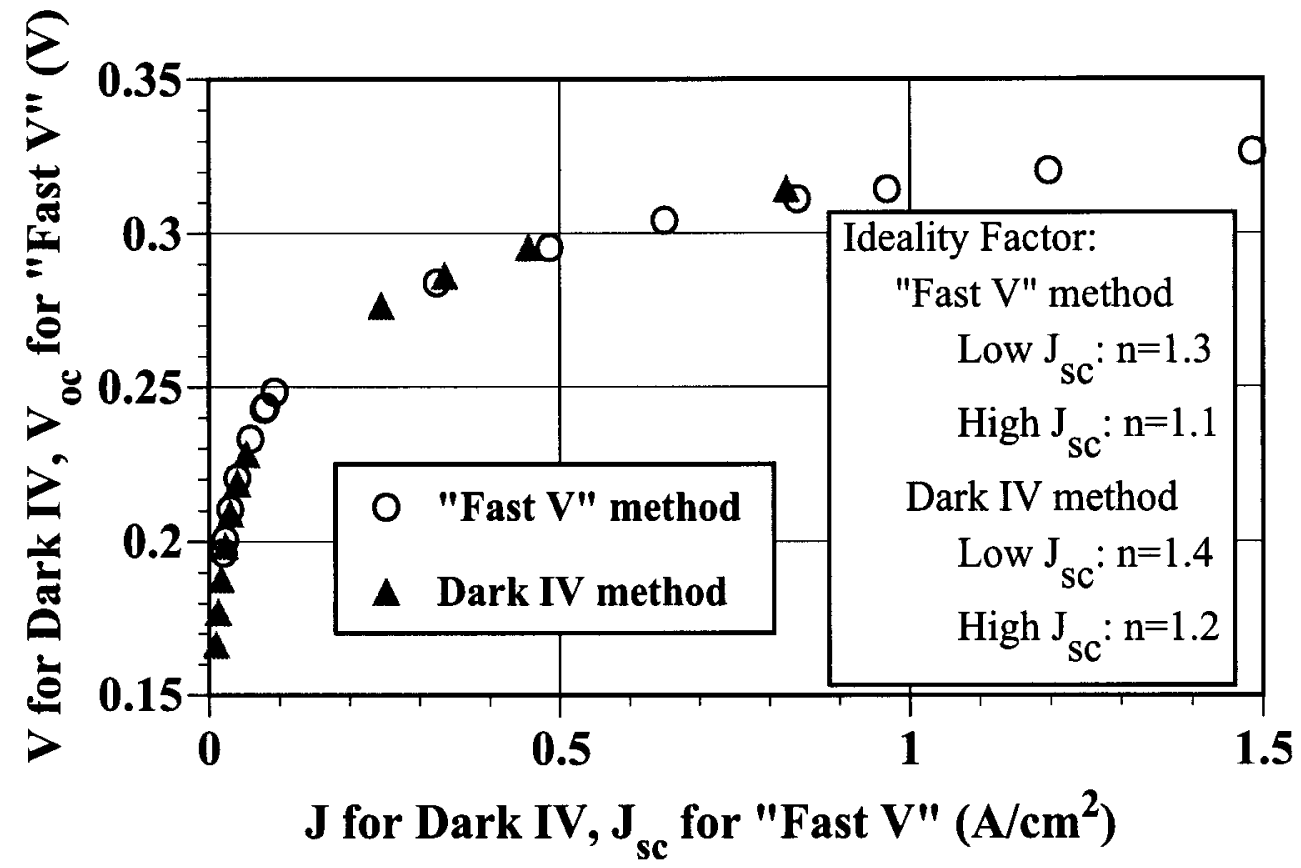

FIGURE 5. Dark I-V and $\mathrm{V}_{\mathrm{oc}}-\mathrm{J}_{\mathrm{sc}}$ pairs for a $0.6-\mathrm{eV}$ GaInAs cell. Note the difference between $V_{o c}$ from fast $\mathrm{V}$ and $\mathrm{V}$ from dark $\mathrm{I}-\mathrm{V}$ at high current density. This corresponds to about a $2.5^{\circ} \mathrm{C}$ difference in temperature that may be due to heating in the first few milliseconds after the shutter opens during fast $\mathrm{V}$ measurement.

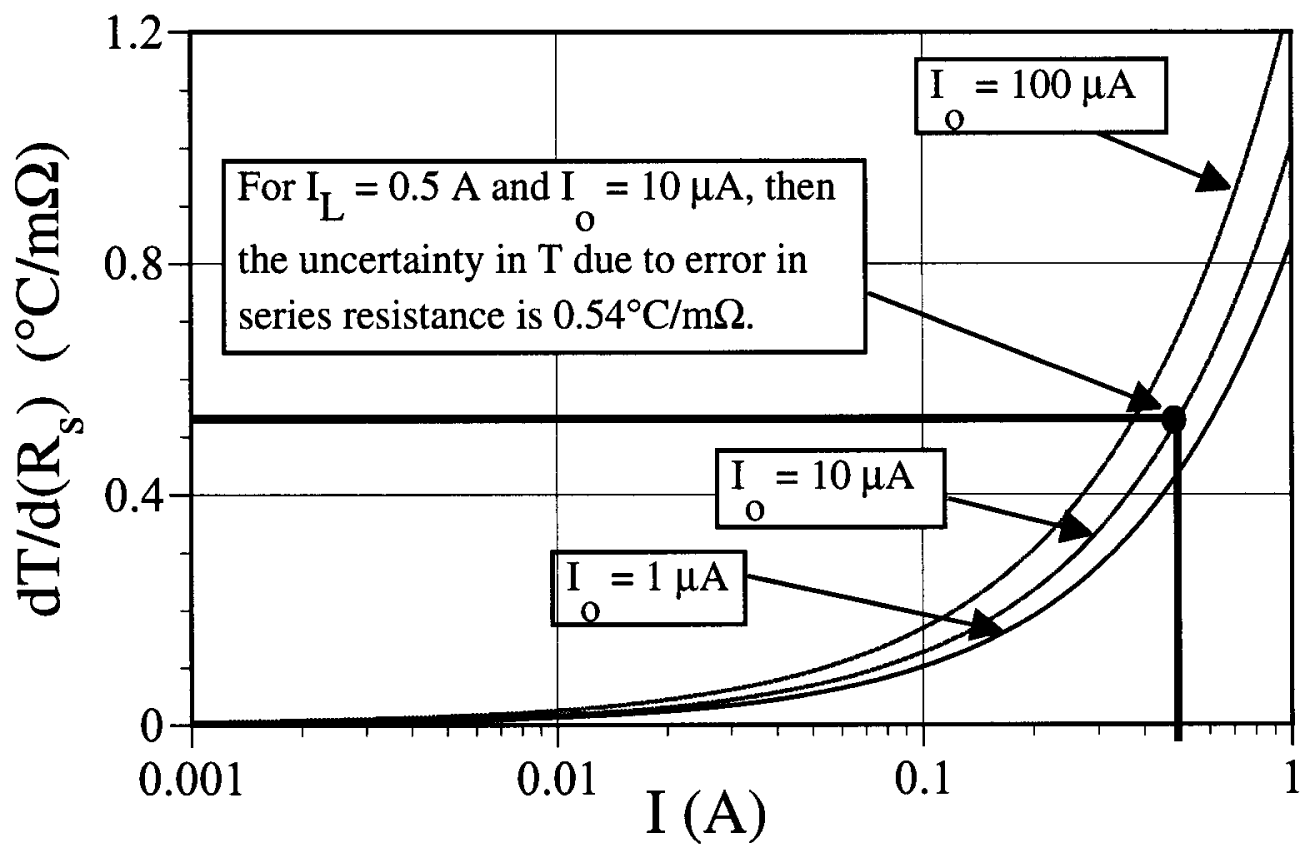

FIGURE 6. Temperature error caused by series resistance when using current-voltage pairs from a dark $\mathrm{I}-\mathrm{V}$ to set $V_{o c}$ and $I_{s c}$ under illumination. It is assumed here that the ideality factor, n, is equal to 1.0. If the series resistance in not well-known to within a few milli-ohms, then temperature errors may be large. 


\section{Flash Simulator}

A high-intensity pulsed solar simulator (HIPSS) is frequently used to measure $I-V$ characteristics of TPV devices at NREL. The HIPSS is capable of delivering up to a $200-\mathrm{W} / \mathrm{cm}^{2}$ (2000 suns) pulse of light with a spatial uniformity within $2 \%$ over a $10 \mathrm{~cm}$ by $10 \mathrm{~cm}$ area for about $1 \mathrm{~ms}$. Typically, only about one-half of the $1-\mathrm{ms}$ pulse is used; therefore, from Equation (2) at $50 \mathrm{~W} / \mathrm{cm}^{2}$, the temperature error is approximately $0.6^{\circ} \mathrm{C}$. Flash simulators have their own set of difficulties [6], but by incorporating correction algorithms for light fluctuations during the pulse and other transient effects we have measured the $I-V$ characteristics of TPV devices with current densities as high as $8 \mathrm{~A} /$ $\mathrm{cm}^{2}$ at $25^{\circ} \mathrm{C}$. It would be very difficult to do this measurement under continuous illumination while maintaining junction temperature. The validity of HIPSS data has been verified at lower current densities by comparing it to data collected using the fast $\mathrm{V}$ method to set the temperature (see Figure 7).

\section{TEMPERATURE COEFFICIENTS}

The measurement of the PV performance at a given temperature requires the accurate determination of the space-charge-region temperature and minimization of temperature-related artifacts discussed in the preceding sections. The data used to generate

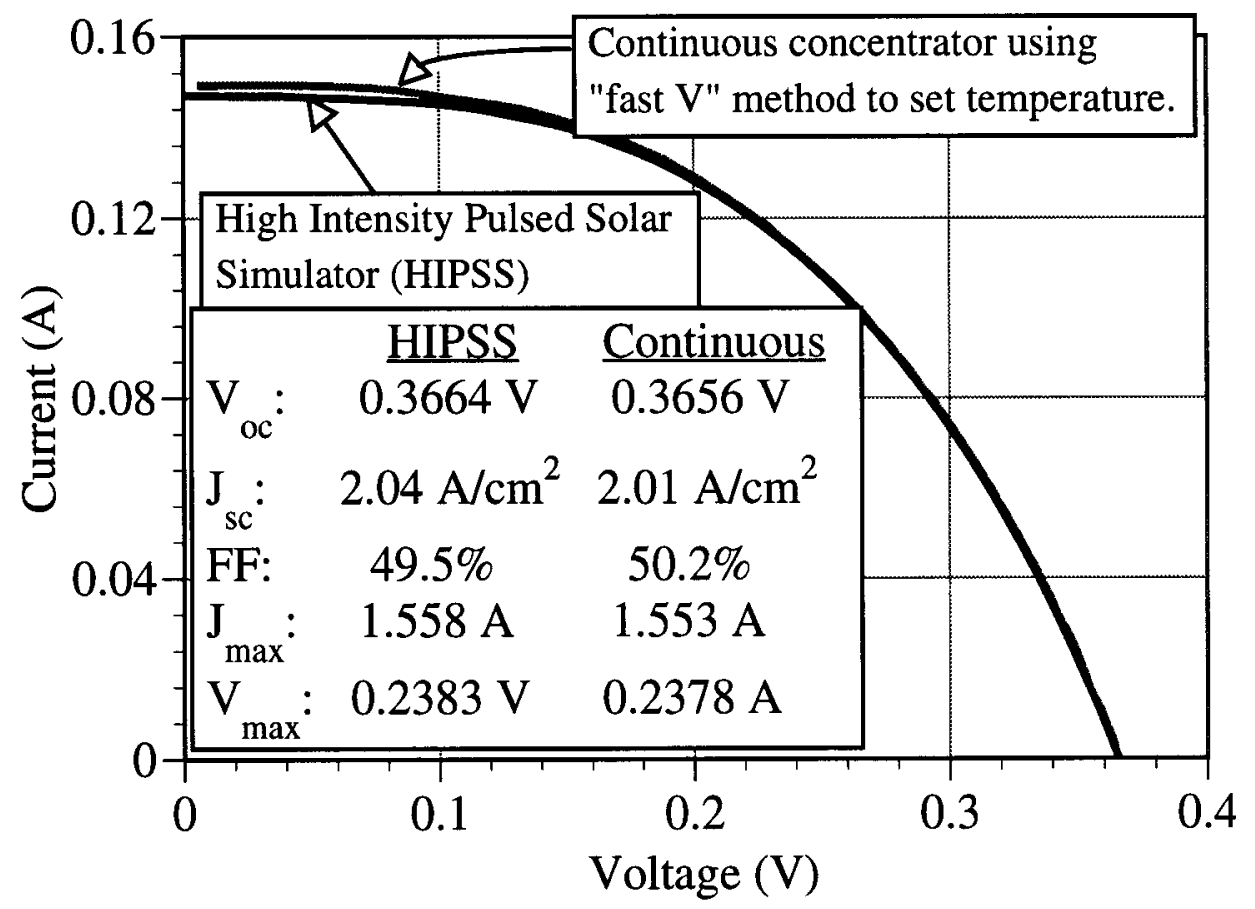

FIGURE 7. I-V data generated under continuous illumination using the "fast $V$ " method to set the temperature to $25^{\circ} \mathrm{C}$ compared to data generated by HIPSS for a $0.073 \mathrm{~cm}^{2}, 0.6-\mathrm{eV} \mathrm{GaInAs}$ cell (8). 
the temperature coefficients in Figure 8 were collected with the HIPSS for a $0.6-\mathrm{eV}$ energy gap GaInAs cell [8]. The temperature coefficient, $T C$, for a given parameter, $Z$, may be written [7] as:

$$
\mathrm{TC}\left(\text { part } /{ }^{\circ} \mathrm{C}\right)=\left.\frac{1}{Z} \frac{\partial \mathrm{Z}}{\partial \mathrm{T}}\right|_{\mathrm{T}_{\mathrm{n}}=25^{\circ} \mathrm{C}}
$$

The temperature coefficient is by convention evaluated at a normalization temperature, $T_{n}$, of $25^{\circ} \mathrm{C}$. The parameters $V_{o c}, I_{s c}, F F$, and $P_{\max }$ for these devices were linear with temperature. Figure 9 illustrates how the quantum efficiency near the bandgap shifts with temperature. Depending on the spectral content of the light source, this shift may or may not be captured, causing potentially large errors in the temperature coefficient of parameters dependent on the photocurrent (i.e. $I_{s c}$ and $P_{\max }$ ). Ideally, the relative spectral irradiance of the light source that the $I-V$ parameters are measured under should be the same as the intended application's light source.

\section{SUMMARY}

Problems that occur in determining temperature while taking $I-V$ data of TPV devices have been noted. These problems are related to poor thermal contact to a temperature-controlled surface, temperature gradients between the front surface and back sur-

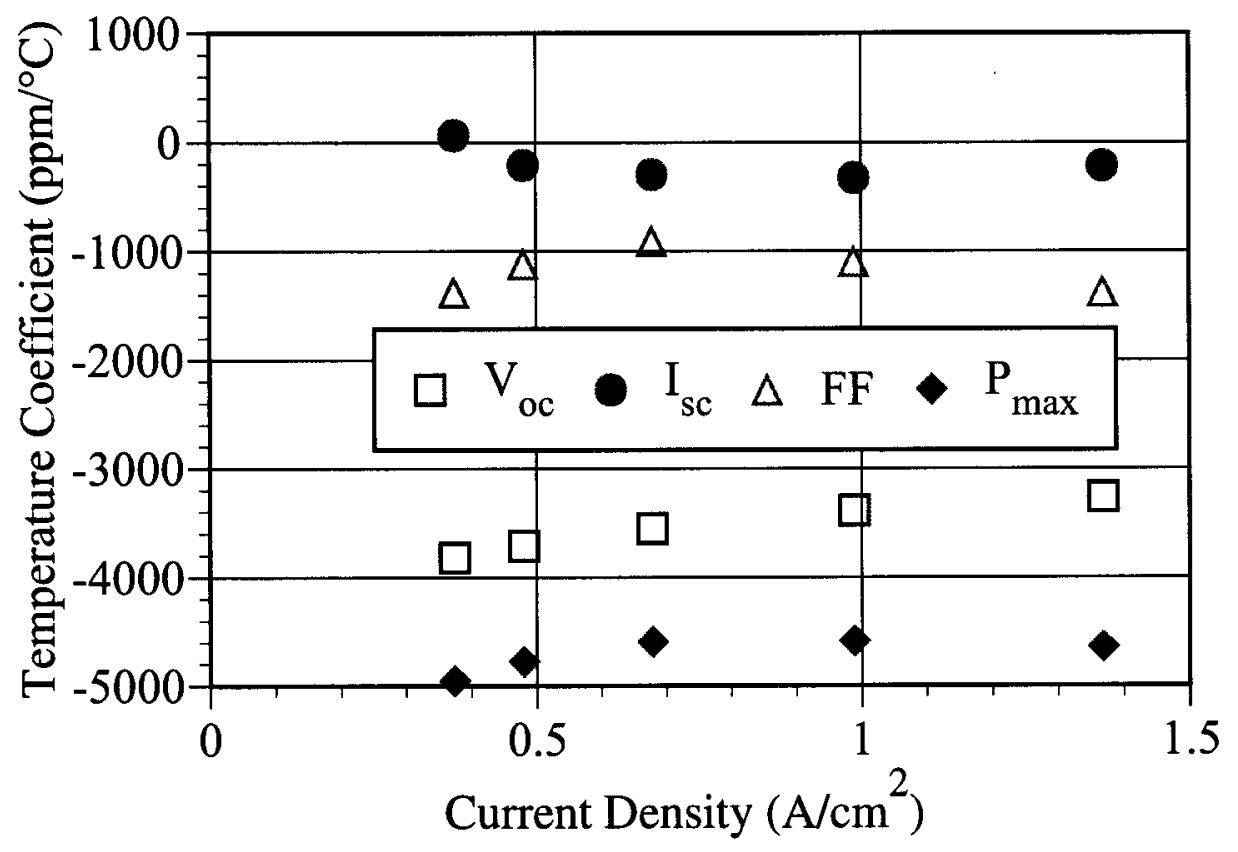

FIGURE 8. The temperature coefficients as a function of current density for a $0.6-\mathrm{eV}$ GaInAs TPV cell. 


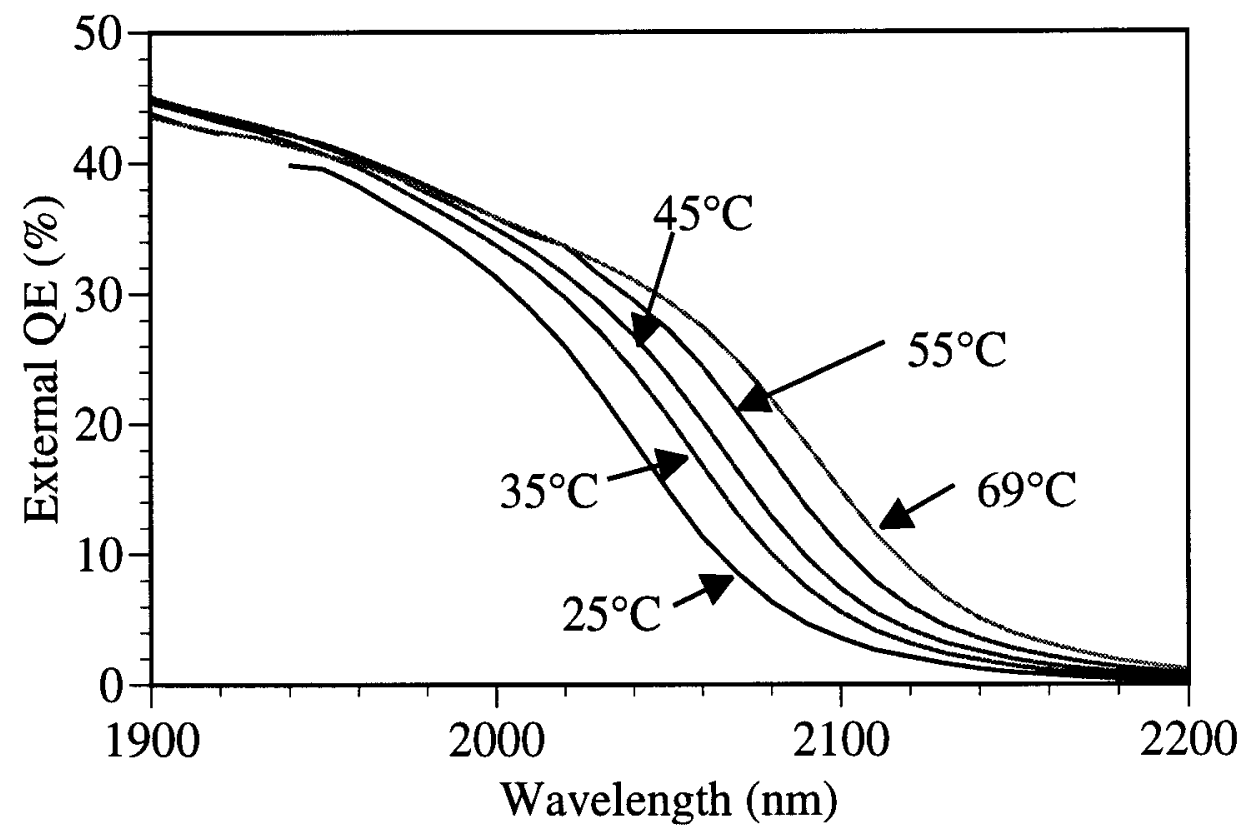

FIGURE 9. Variation in the external quantum efficiency with temperature for a $0.6-\mathrm{eV}$ GaInAs cell [8] showing the temperature dependence of the energy gap.

face, and the junction temperature. Temperature-related issues of determining the dark current and diode quality factor from $V_{o c}$ versus $J_{s c}$ data compared with the limitations of dark $I-V$ measurements were discussed. Several strategies for mitigating temperaturerelated problems and their potential errors have been presented. Temperature coefficients for several cell parameters, and temperature dependence of the quantum efficiency near the energy gap for 0.6-eV GaInAs TPV devices, have been plotted.

\section{ACKNOWLEDGEMENTS}

The authors wish to thank M. Wanlass, S. Ward, A. Duda and J. Carapella of the National Renewable Energy Laboratory for providing the TPV devices that were evaluated for this paper. The authors wish to also thank C. Murray and B. Wernsman of Bettis Atomic Physics Laboratory for their helpful suggestions.

\section{REFERENCES}

1. Sanderson, R. W., O'Donnell, D. T., and Backus, C. E., "The Effects of Nonuniform Illumination and Temperature profiles on Silicon Solar Cells Under Concentrated Sunlight," Proc. $14^{\text {th }}$ IEEE Photovoltaic Specialists Conference, San Diego, CA, Jan 6-10, 1980, pp. 431-436. 
2. Nasby, R. D., and Sanderson, R. W., "Performance Measurement Techniques for Concentrator Photovoltaic Cells," Solar Cells, 6, pp. 39-47, (1982).

3. Emery, K. A., and Osterwald, C. R., Efficiency Measurements and Other Performance Rating Methods, Current Topics in Photovoltaics, 3, pp. 301-349, T.J. Coutts editor, Academic Press, 1988.

4. Borden, P. G., LaRue, R. A., Gregory, P. E., and Boettcher, R., "The Flash Testing of AlGaAs/GaAs Concentrator Solar Cells," Proc. 15 ${ }^{\text {th }}$ IEEE Photovoltaic Specialists Conference, Kissimmee, FL, May 12-15, 1981, pp. 193-196.

5. Adachi, S., Physical Properties of III-V Semiconductor Compounds InP, InAs, GaAs, GaP, InGaAs and InGaAsP, New York: John Wiley \& Sons, 1992.

6. Winter, S., and Metzdorf, J., "Correction Procedures for the Flasher Calibration of PV Devices Resulting in Reduced Restrictions and Uncertainties," Proc. $2^{\text {nd }}$ World PV Conference and Exhibition, Vienna, Austria, July 6-11, 1998.

7. Emery, K., Burdick, J., Caiyem, D., Dunlavy, D., Field, H., Kroposki, B., Moriarty, T., Ottoson, L., Rummel, S., Strand, T., and Wanlass, M. W., "Temperature Dependence of Photovoltaic Cells, Modules, and Systems," Proc. $25^{\text {th }}$ IEEE Photovoltaic Specialists Conference, Washington D.C. May 13-17, 1996, pp. 1275-1278.

8. Wanlass, M. W., Carapella, J. J., Duda, A., Emery, K., Gedvilas, L., Moriarty, T., Ward, S., Webb, J., Wu, X., and Murray, C. S., "High Performance $0.6 \mathrm{eV}$, $\mathrm{Ga}_{0.32} \mathrm{In}_{0.68} \mathrm{As} / \mathrm{InAs}_{0.32} \mathrm{P}_{0.68}$ Thermophotovoltaic Converters and Monolithically Interconnected Modules," Proc. 4th NREL Thermophotovoltaic Generation of Electricity Conference, Denver, CO, October 11-14, 1998. 